\title{
QUALITY OF GROUNDWATER AND AQUATIC HUMIC SUBSTANCES FROM MAIN RESERVOIRE OF GROUND WATER No. 333
}

\author{
Izabella Pisarek', Mariusz Głowacki \\ 1 Department of Land Protection, Opole University, 22 Oleska St., 45-052 Opole, Poland, e-mail: izapis@uni. \\ opole.pl, marglo@uni.opole.pl
}

Received: 2015.08 .07

Accepted: 2015.10 .06

Published: 2015.11.10

\begin{abstract}
The conducted research included the estimation of the quality of groundwater from the Main Reservoir of Ground Water No. 333 area in Opole District, Poland. The groundwater in the analyzed region shows high diversity in quality. The main threat for the quality of water in this region is the human household activity. The main pollutants of groundwater are: dissolved phosphorus, nitrate and ammonium. The quality and quantity of dissolved humic substances in groundwater were also investigated. The results showed that the contents of water-extractable organic carbon varied. Presently, the analyzed groundwater is characterized by large differences in dissolved forms of organic carbon. During migration of the soil solution through the soil profile to groundwater, dissolved humic substances undergo qualitative and quantitative changes. Correlation analysis between the quantity of carbon in soil and aquatic humic substances, especially fulvic acids, indicates the possibility of their translocation in soil profiles and their transformation and migration to groundwater. This conclusion can be confirmed by FT-IR-analysis.
\end{abstract}

Keywords: groundwater, humic substances, dissolved organic carbon.

\section{INTRODUCTION}

Agricultural activities influence soil processes and can shape the chemistry of underground water. The quality of underground water depends on the circulation of geochemical and biological materials, soil properties, mobility of elements, biological sorption, and can be modified by anthropogenic activity [Aiken, 1985; Pisarek and Głowacki, 2005; Steinberg et al., 2003]. The balance of nutrients in the soils in rural areas is very unstable, due to difficulties in adjusting their amounts to the actual needs of plants and overproduction of organic fertilizers. As a result, a large part of nutrients move beyond the reach of the root system, is leached from the soil profiles and can infiltrate to the aquatic system. The content of organic carbon has also significant effects on water quality. Especially humic substances play an important role in the aquatic system. In the freshwater approximately $90 \%$ of total organic matter occurs as dissolved forms [Górniak, 1996;
Zieliński 2004]. During the translocation from the mineral soil to the groundwater humus substances undergo changes in quantity and quality [Allahbakhh et al., 2014; Lydersen et al., 1996; Pisarek and Głowacki, 2005]. Humic substances, with predominating fulvic acids and their complexes with metal ions, represent the main component of dissolved organic carbon. Organo-mineral complexes play an important role as a significant factor determining the circulation of xenobiotics from the soil profiles to the ground water.

Therefore, their content, chemical properties and biological activity are different from humic substances extracted from soils. The solution chemistry of humic substances is influenced by functional group heterogeneity and variations in molecular size distribution is gaining considerable acceptance among researches studying dissolved organic matter [Ephraim et al., 1996].

Aquatic humic substances are polar, yellow colored, organic acids that are derived from soil humus. The role of humic substances in water 
chemistry is receiving increasing attention because humic substances are known as complexes with metal ions, and they are implicated in the complexation or solubilization of pesticides and hydrocarbons in the aqueous environment [Aiken, 1985; Steinberg et al., 2003].

The report presents the quality of ground water and properties of dissolved humic substances. We also studied the possibility of humic substances transfer from soil to underground water.

\section{LOCALIZATION AND PROPERTIES OF INVESTIGATED AREA}

The investigated area was located in the Main Reservoir of Ground Water (MRGW) No. 333 (Opole District, Poland). This region is situated in the western part of the Silesian Upland. The area where the erupting volcano went through Triassic limestone and formed sediments of basaltic cone on layers of limestone is nowadays protected as "St. Anna Mountain" Landscape-Protection Park. The limestone layers and their penetration by nonporous, little-eroding basaltic rocks created good conditions for karst phenomena. The bottom of the mountain and the adjacent areas are used for agricultural purposes. The farmers grow various crops and breed stock animals.

Soil profiles of this region represented mainly: Eutric Cambisols, Cambic Rendzinas, Stagnic Humic Gleysols, and Haplic Podzol, and showed profile differences in the content of floatable and colloidal particles $(<0,02 \mathrm{~mm},<0,002 \mathrm{~mm})$, was presented in previous work [Pisarek and Głowacki, 2009]. Variability of the parent rocks (sand, sandy loam sandy grovel, clay silt, silt) and soil usage (intensive farming) influenced the development of the physico-chemical and chemical properties of soils of this region.

\section{METHODS}

Researches of groundwater quality in the region of St. Anna Mountain were carried out by taking the samples from 17 wells (situated nearby households) in the period between January and December (the same year).

The following parameters were determined in water samples (using ordinary methods): $\mathrm{pH}$, conductivity, color, $\mathrm{C}_{\text {total }}$ (calculated as COD-Cr after determination by the chromate method), dissolved phosphate, ammonium, nitrate, nitrite, content of $\mathrm{CaCO}_{3}$ (calculated after determination of hardness).

The dissolved forms of phosphate were determined by a spectrometric method with vanadium-molibdenum-ammonium and zinc chloride as reducing agents. Nitrate was determined by a method with sodium salicylate, nitrite was determined with 1-naphtylamine and sulphanilic acid. Ammonium was determined with the Nessler indicator. COD-Cr was determined with ferroine as an indicator and Mohr salt. Hardness was determined with the use of the EDTA method in ammonium buffer.

Dissolved humic substances from groundwater were determined with the use of the method elaborated by Górniak [1995]. FTIR spectra of dissolved organic carbon (from groundwater) in $4000-400 \mathrm{~cm}^{-1}$ were taken. In soil samples (of MRGW area) originating from A horizons the following characteristics were determined: total carbon, according to the oxymetric method by Tiurin and the fractional composition of humic substances by the Kononowa-Bielczikowa [Kononova, 1966; Pisarek, 2003].

All analyses were performed in triplicates and the results (in tables and figures) are reported as their arithmetical averages. Correlation coefficients were done for all results.

\section{RESULTS AND DISCUSSION}

Small part of soil humic substances as "a water dissolved fraction" plays an in important role in the environment [Aiken, 1985; Artinger et al., 2000; Steinberg et al., 2003]. Dissolved organic substances at aquatic ecosystems comprises different types of organic compounds, some of which are produced autochthonously, but most are of allochthonous origin [Arvola and Tulonen, 1998]. The allochthonous fraction of dissolved organic substances consists of a broad spectrum of nonhumic and humic substances, including complex structures of aromatic and aliphatic groups. It may undergo elution into deeper layers of the soil profile as well as into ground waters and may participate in microorganism, metals and xenobiotics transportation. The type of the land used (agricultural or forest) determines plant production and the character of organic material introduced into the soil [Arvola and Tulonen, 1998; Mattson and Kortelainen, 1998; Zieliński, 2004]. A particularly large variety in the quality of dissolved organic 
matter was observed in soils under agricultural use with different farming practice. Aiken and Cotsaris [1995] found the type of soil had a large impact on the amount and character of dissolved organic matter infiltration to groundwater.

Variability of the parent rocks and soil usage (intensive farming) influenced the development of the physico-chemical and chemical properties of soils in the investigated area was presented in a previous work [Pisarek and Głowacki, 2009]. In soils of this area we observed varying accumulation of total organic carbon and quantitative differences in humic fractions. Analysis of fractional composition of soil organic matter indicates different carbon accumulation in isolated humic fractions (Figure 1). Substantial differences were observed in the quantity of humic substances isolated by the mixture of $0,1 \mathrm{M} \mathrm{Na}_{4} \mathrm{P}_{2} \mathrm{O}_{7}+0,1$ $\mathrm{M} \mathrm{NaOH}$ (fraction 1), which extracts free humic compounds and humic compounds associated with $\mathrm{Ca}$, and non-silicate forms of $\mathrm{R}_{2} \mathrm{O}_{3}$ isolated by $0,1 \mathrm{M} \mathrm{NaOH}$ solution (fraction 2). According to the described methods [Pisarek, 2003], the differences in the solubility of humic substances allow the calculation of the amount of carbon in humic substances associated with calcium $\left(\mathrm{CHA}_{\mathrm{Ca}}\right)$. Transformation of organic matter in the investigated soils lead to the formation of these complexes in Eutric Cambisol and Rendzinas (profiles 1, 4 and 6). Our previous investigations [Pisarek and Głowacki 2009] showed also a clear differentiation in quality of dissolved organic carbon in the studied soils. The content of carbon in soil water solutions varied in the studied soils and showed simultaneously the differentiation in the quantity of dissolved forms of humic substances.

The depth of investigated wells was diverse and ranged from 0.9 to $12.5 \mathrm{~m}$ between ground surface and groundwater surface. Despite differences in appearance, water from various depths was characterized by $\mathrm{pH}$ between 6,24 to 7,85 (Table 1). Conductivity of this water was on an average level and indicated a medium value of the total dissolved salts.

The properties of all taken water samples differed significantly. The content of total organic carbon differed between 0,70 to $16,39 \mathrm{mg} \cdot \mathrm{dm}^{-3}$ and their dynamics (expressed by coefficient of variation [V]) increased with concentration of $\mathrm{C}_{\text {total }}$ (Figure 2). The same relationship was observed for $\mathrm{C}_{\text {humic }}$ (Figure 3). Between $\mathrm{C}_{\text {total }}$ and $\mathrm{C}_{\text {humic }}$ a strong correlation was calculated $(\mathrm{r}=0,984$ for January, $r=0,992$ for May, $r=0,995$ for November). It showed the possibility of translocation of the analyzed organic forms of carbon from the same source (probably from soils with intensive agricultural activity) to ground water.

The results show that aquatic humic substances from different places have dissimilar properties which differ from one another. Systematic differences are found among humic substances from different regions of the MRGW in Opole district.

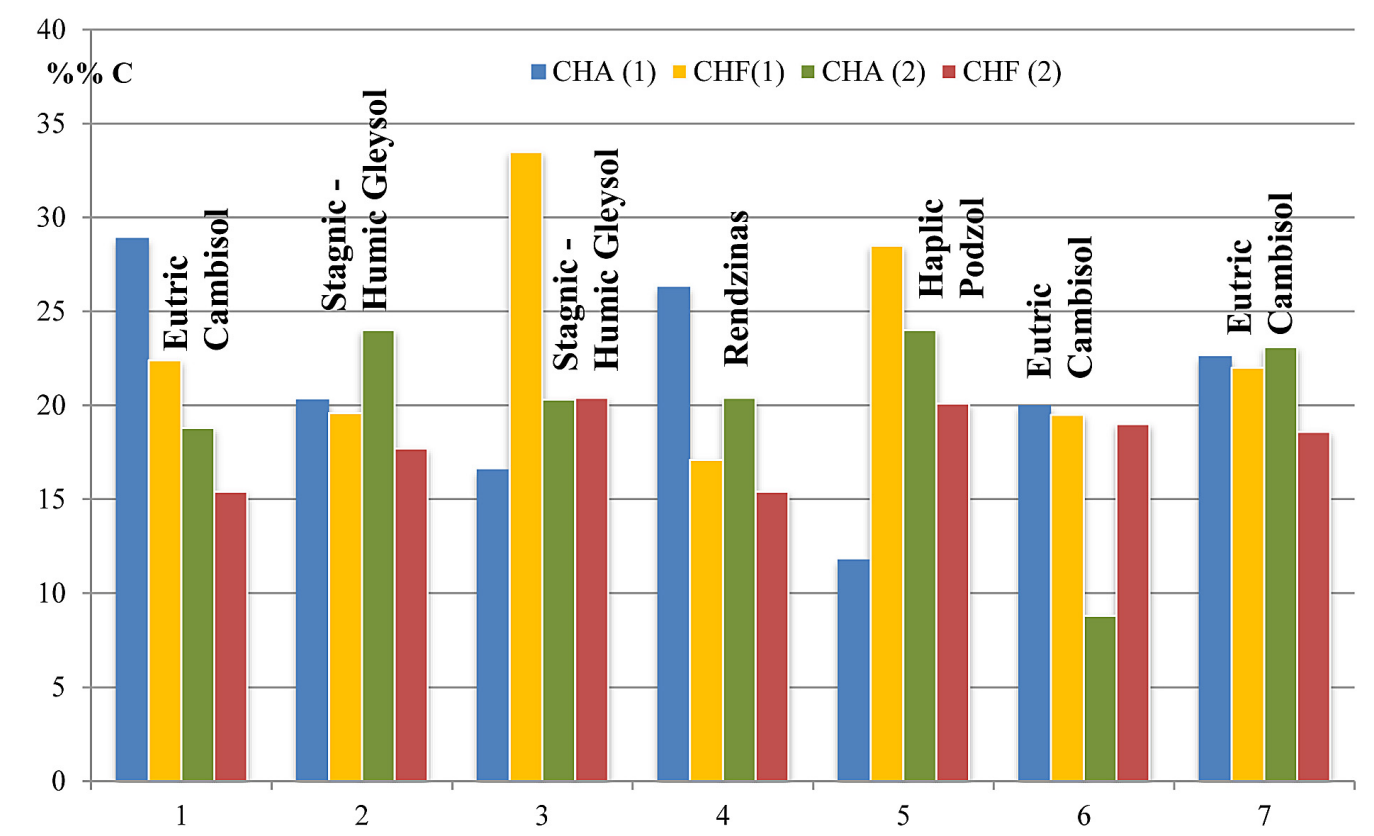

Figure 1. Fractional composition of humic substances in the investigated soils (in $\% \%$ of Ctotal): CHA (1) - humic acids of fraction 1; CFA (1) - fulvic acids of fraction 1; CHA (2) - humic acids of fraction 2; CFA (2) - fulvic acids of fraction 2 
Table 1. Some properties of analyzed groundwater

\begin{tabular}{|c|c|c|c|c|c|c|c|c|}
\hline \multirow{2}{*}{ No of sample } & \multirow{2}{*}{$\mathrm{pH}$} & \multirow{2}{*}{ Conductivity, $\mu S$} & \multirow{2}{*}{$\begin{array}{c}\text { Color } \\
\mathrm{Mg} \mathrm{Pt} \cdot \mathrm{dm}^{-3}\end{array}$} & $\mathrm{CaCO}_{3}$ & $\mathrm{NH}_{4}^{+}$ & $\mathrm{NO}^{2-}$ & $\mathrm{NO}^{3-}$ & $\mathrm{PO}_{4}{ }^{3-}$ \\
\hline & & & & \multicolumn{5}{|c|}{$\mathrm{mg} \cdot \mathrm{dm}^{-3}$} \\
\hline \multicolumn{9}{|c|}{ January } \\
\hline 1 & 7.05 & 760 & 6.7 & 295 & 0.038 & 0.005 & 4.92 & 0.317 \\
\hline 2 & 7.60 & 103 & 21.9 & 51 & 0.258 & 0.111 & 3.52 & 1.055 \\
\hline 3 & 7.11 & 570 & 6.4 & 190 & 0.027 & 0.004 & 4.80 & 5.165 \\
\hline 4 & 6.92 & 609 & 7.6 & 322 & 0.062 & 0.004 & 4.79 & 6.090 \\
\hline 5 & 7.39 & 499 & 11.7 & 229 & 0.105 & 0.017 & 4.81 & 0.146 \\
\hline 6 & 7.00 & 695 & 13.1 & 272 & 0.386 & 0.065 & 4.77 & 2.272 \\
\hline 7 & 7.13 & 713 & 7.1 & 252 & 0.022 & 0.005 & 4.78 & 0.832 \\
\hline 8 & 7.04 & 649 & 5.9 & 256 & 0.057 & 0.0 & 4.80 & 0.055 \\
\hline 9 & 7.00 & 685 & 11.5 & 171 & 0.226 & 0.029 & 4.24 & 7.635 \\
\hline 10 & 7.04 & 695 & 8.5 & 283 & 0.041 & 0.007 & 4.87 & 6.250 \\
\hline 11 & 7.85 & 408 & 8.1 & 218 & 0.0 & 0.0 & 8.40 & 0.359 \\
\hline 12 & 7.31 & 366 & 9.5 & 169 & 0.005 & 0.002 & 15.17 & 0.122 \\
\hline 13 & 7.68 & 768 & 9.1 & 290 & 0.077 & 0.001 & 17.09 & 0.348 \\
\hline 14 & 6.68 & 460 & 11.7 & 171 & 0.068 & 0.001 & 18.42 & 5.220 \\
\hline 15 & 6.68 & 620 & 14.0 & 225 & 0.231 & 0.002 & 15.63 & 0.169 \\
\hline 16 & 6.62 & 619 & 16.8 & 194 & 0.532 & 0.039 & 18.56 & 0.293 \\
\hline 17 & 6.24 & 502 & 11.3 & 169 & 0.019 & 0.001 & 20.69 & 0.576 \\
\hline Variability index [\%] & 5.7 & 29.7 & 39.2 & 30.0 & 119.2 & 173.8 & 67.8 & 124.0 \\
\hline \multicolumn{9}{|c|}{ May } \\
\hline 1 & 6.99 & 788 & 6.2 & 425 & 0.068 & 0.003 & 4.87 & 0.479 \\
\hline 2 & 6.76 & 780 & 6.0 & 50 & 0.412 & 0.068 & 1.62 & 0.566 \\
\hline 3 & 6.56 & 569 & 58.0 & 234 & 0.119 & 0.008 & 4.74 & 4.020 \\
\hline 4 & 6.18 & 632 & 11.5 & 250 & 0.079 & 0.004 & 4.75 & 4.630 \\
\hline 5 & 6.33 & 664 & 23.5 & 300 & 1.073 & 0.094 & 3.89 & 4.170 \\
\hline 6 & 6.90 & 452 & 5.8 & 210 & 0.190 & 0.007 & 8.30 & 0.160 \\
\hline 7 & 6.35 & 667 & 7.3 & 289 & 0.120 & 0.007 & 4.69 & 0.739 \\
\hline 8 & 6.23 & 663 & 4.5 & 321 & 0.039 & 0.0 & 4.74 & 0.125 \\
\hline 9 & 6.11 & 628 & 22.4 & 217 & 0.832 & 0.133 & 2.74 & 4.650 \\
\hline 10 & 6.19 & 932 & 8.2 & 318 & 0.0 & 0.002 & 4.83 & 4.660 \\
\hline 11 & 7.05 & 435 & 10.6 & 183 & 0.170 & 0.004 & 8.20 & 0.450 \\
\hline 12 & 7.40 & 423 & 8.2 & 161 & 0.240 & 0.017 & 9.70 & 0.130 \\
\hline 13 & 6.66 & 643 & 7.5 & 221 & 0.190 & 0.004 & 8.80 & 0.650 \\
\hline 14 & 6.42 & 534 & 7.1 & 142 & 0.270 & 0.017 & 9.72 & 2.830 \\
\hline 15 & 6.78 & 455 & 7.3 & 144 & 0.250 & 0.002 & 1.50 & 0.160 \\
\hline 16 & 6.73 & 443 & 12.9 & 175 & 0.670 & 0.046 & 8.12 & 0.230 \\
\hline 17 & 6.45 & 484 & 5.2 & 142 & 0.290 & 0.008 & 9.11 & 0.510 \\
\hline Variability index [\%] & 5.5 & 24.3 & 103.8 & 40.2 & 100.7 & 152.0 & 47.0 & 111.4 \\
\hline \multicolumn{9}{|c|}{ November } \\
\hline 1 & 7.02 & 832 & 4.4 & 331 & 0.041 & 0.0 & 7.54 & 0.322 \\
\hline 2 & 7.42 & 446 & 5.3 & 155 & 0.0 & 0.0 & 6.76 & 2.121 \\
\hline 3 & 7.07 & 605 & 4.0 & 235 & 0.457 & 0.030 & 7.06 & 4.268 \\
\hline 4 & 6.90 & 885 & 5.5 & 188 & 0.0 & 0.005 & 4.94 & 2.669 \\
\hline 5 & 7.17 & 836 & 5.1 & 393 & 0.0 & 0.001 & 6.56 & 0.176 \\
\hline 6 & 7.24 & 1145 & 12.8 & 350 & 9.330 & 0.007 & 0.0 & 5.590 \\
\hline 7 & 7.30 & 718 & 6.0 & 262 & 0.079 & 0.002 & 1.84 & 0.901 \\
\hline 8 & 7.23 & 649 & 4.5 & 256 & 0.0 & 0.0 & 7.26 & 0.308 \\
\hline 9 & 7.09 & 622 & 10.0 & 182 & 0.087 & 0.058 & 3.80 & 3.001 \\
\hline 10 & 7.23 & 770 & 6.0 & 285 & 0.285 & 0.0 & 6.88 & 3.906 \\
\hline 11 & 8.33 & 372 & 6.9 & 210 & 0.473 & 0.020 & 6.88 & 0.640 \\
\hline 12 & 7.88 & 363 & 7.2 & 175 & 0.0 & 0.0 & 7.82 & 0.139 \\
\hline 13 & 7.08 & 895 & 6.9 & 369 & 0.0 & 0.117 & 8.48 & 0.327 \\
\hline 14 & 7.05 & 506 & 6.2 & 144 & 0.172 & 0.002 & 8.52 & 2.250 \\
\hline 15 & 7.52 & 582 & 11.0 & 235 & 0.228 & 0.007 & 8.16 & 0.234 \\
\hline 16 & 7.52 & 424 & 12.1 & 205 & 0.0 & 0.012 & 8.10 & 0.339 \\
\hline 17 & 6.67 & 498 & 6.2 & 167 & 0.0 & 0.002 & 8.62 & 0.270 \\
\hline Variability index [\%] & 5.3 & 33.0 & 38.5 & 32.0 & 341.6 & 194.8 & 38.0 & 107.1 \\
\hline
\end{tabular}




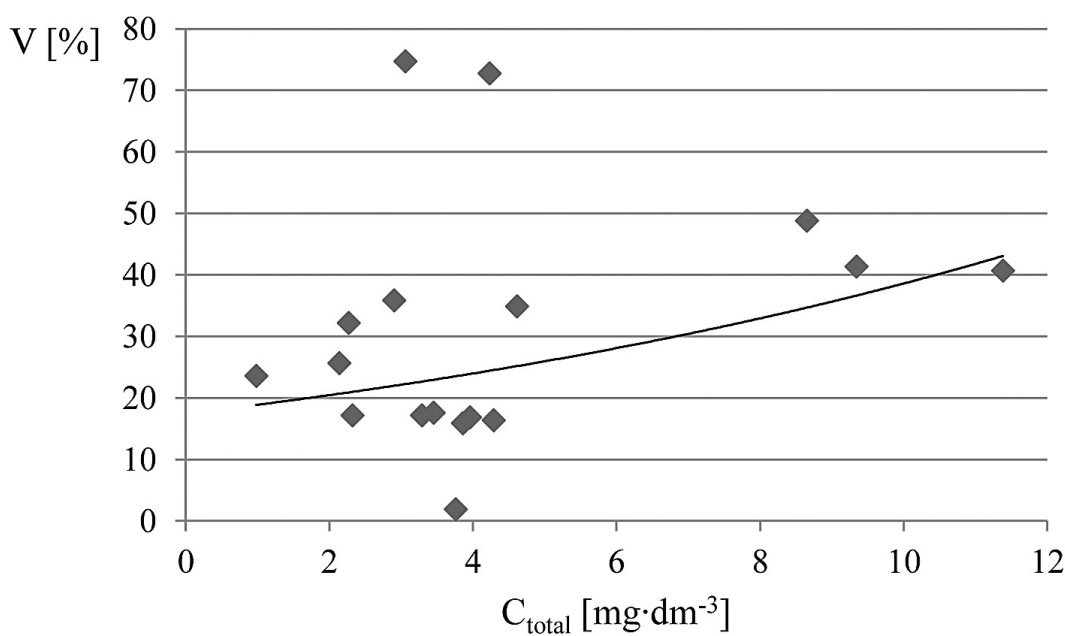

Figure 2. Interdependence between total forms of dissolved organic carbon in groundwater and coefficient of variation $(\mathrm{r}=0,532)$

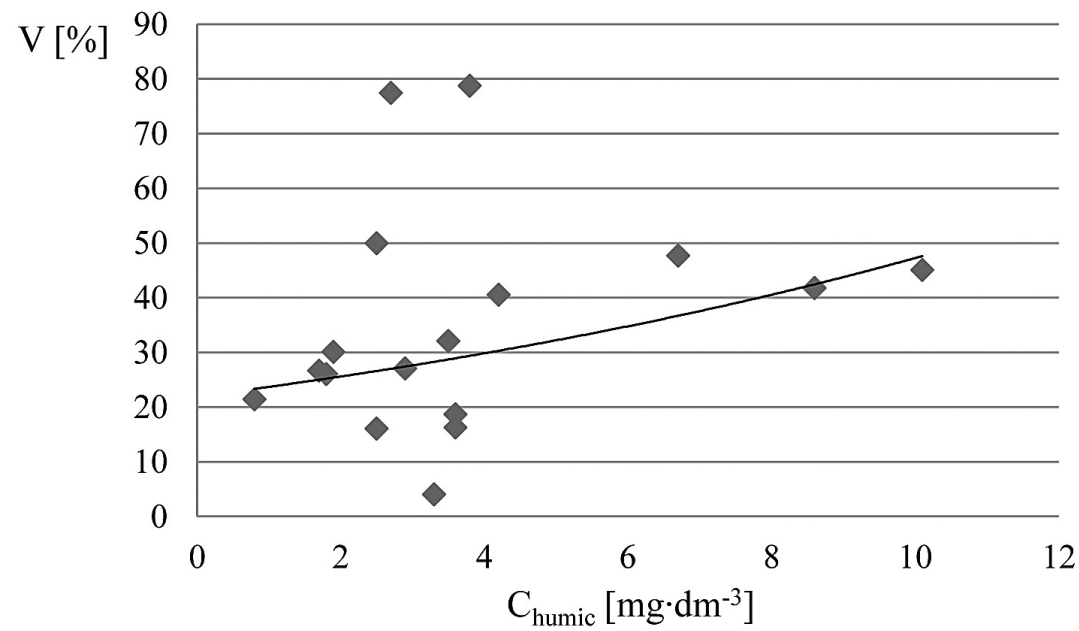

Figure 3. Interdependence between carbon of humic substances in groundwater and coefficient of variation $(\mathrm{r}=0,489)$

Such differences are considered to be caused by mixing humic substances infiltration from the soil. However, the quantity and quality of humic substances can also be created by the overlapping effects of different geochemical processes and human activity. These results were quite consistent with researches of Tremblay and Gagene [2009]. They observed that most aquatic humic substances were formed on land. Moreover, the formation on humic substances by sorption onto the mineral matrix can be promoted by large proportions of silt and clay.

The content of dissolved forms of phosphorus in analyzed water was high. Acceptable value of phosphorus in ground waters, which are used, should not exceed $5 \mathrm{mg} \cdot \mathrm{dm}^{-3}$ (by the Regulation of the Polish Ministry of the Environment [2008]) and it was higher in six of the investigated water samples from January and one from Decem- ber take off and excess over this limit was very large. In other wells the quality of water was better, the content of phosphorus was lower and it varied from 0,055 to $4,640 \mathrm{mg} \cdot \mathrm{dm}^{-3}$. In Poland, it is a typical content of phosphorus in ground water in agricultural areas. The content of $\mathrm{CaCO}_{3}$ in analyzed water is very high and it results from the content of minerals in the ground - the occurrence of limestone in this region.

The content of the analyzed nitrogen forms varied and showed diversification between water samples. It was confirmed by high value of the variability index (Table 1). The colour of waters depends mainly on dissolved organic matter. High content of dissolved organic carbon in groundwater very often is due to the specific soil cover and human activity. The correlation between the value of water color, $\mathrm{NH}_{4}^{+}$and the value of $\mathrm{C}_{\text {total }}$ and $\mathrm{C}_{\text {humic }}$ were high in January and December taken 
Table 2. Changing of total and humic forms of organic carbon in analyzed groundwater

\begin{tabular}{|c|c|c|c|c|c|c|}
\hline \multirow{3}{*}{ No of sample } & \multicolumn{6}{|c|}{ Scientific term } \\
\hline & \multicolumn{2}{|c|}{ January } & \multicolumn{2}{|c|}{ May } & \multicolumn{2}{|c|}{ November } \\
\hline & $\begin{array}{c}\mathrm{C}_{\text {total }} \\
\mathrm{mg} \cdot \mathrm{dm}^{-3}\end{array}$ & $\begin{array}{c}\mathrm{C}_{\text {humic }} \\
\mathrm{mg} \cdot \mathrm{dm}^{-3}\end{array}$ & $\begin{array}{c}\mathrm{C}_{\text {total }} \\
\mathrm{mg} \cdot \mathrm{dm}^{-3}\end{array}$ & $\begin{array}{c}\mathrm{C}_{\text {humic }} \\
\mathrm{mg} \cdot \mathrm{dm}^{-3}\end{array}$ & $\begin{array}{c}\mathrm{C}_{\text {total }} \\
\mathrm{mg} \cdot \mathrm{dm}^{-3}\end{array}$ & $\begin{array}{c}\mathrm{C}_{\text {humic }} \\
\mathrm{mg} \cdot \mathrm{dm}^{-3}\end{array}$ \\
\hline 1 & 1.61 & 1.30 & 2.71 & 2.23 & 2.1 & 1.88 \\
\hline 2 & 3.50 & 2.72 & 4.03 & 3.74 & 2.82 & 2.20 \\
\hline 3 & 3.55 & 2.23 & 4.95 & 4.33 & 4.38 & 4.01 \\
\hline 4 & 3.21 & 2.80 & 4.16 & 3.96 & 4.50 & 3.96 \\
\hline 5 & 2.52 & 1.85 & 2.58 & 2.08 & 1.86 & 1.20 \\
\hline 6 & 5.90 & 5.45 & 13.53 & 12.50 & 8.58 & 7.80 \\
\hline 7 & 3.61 & 2.96 & 3.63 & 2.35 & 2.64 & 2.20 \\
\hline 8 & 1.16 & 0.95 & 1.06 & 0.64 & 0.72 & 0.70 \\
\hline 9 & 3.15 & 2.89 & 4.22 & 3.80 & 4.20 & 3.96 \\
\hline 10 & 2.69 & 2.40 & 4.03 & 3.88 & 1.98 & 1.35 \\
\hline 11 & 0.80 & 0.52 & 5.10 & 4.52 & 6.78 & 6.41 \\
\hline 12 & 3.02 & 2.57 & 4.56 & 4.02 & 6.24 & 5.95 \\
\hline 13 & 0.91 & 0.88 & 2.82 & 2.20 & 5.46 & 4.94 \\
\hline 14 & 3.71 & 3.14 & 3.72 & 3.32 & 3.84 & 3.40 \\
\hline 15 & 11.97 & 8.21 & 3.90 & 3.01 & 10.08 & 8.78 \\
\hline 16 & 16.39 & 15.12 & 10.50 & 8.64 & 7.26 & 6.40 \\
\hline 17 & 1.43 & 1.32 & 2.64 & 2.48 & 2.75 & 2.02 \\
\hline Variability index [\%] & 100.6 & 95.5 & 65.6 & 69.4 & 57.9 & 61.5 \\
\hline
\end{tabular}

Table 3. Correlation coefficients between some parameters of the investigation

\begin{tabular}{|c|c|c|}
\hline Feature $(X)$ & Feature $(Y)$ & $r$ \\
\hline \multicolumn{3}{|c|}{ January } \\
\hline \multirow{3}{*}{$C_{\text {total }}$} & Color & $0.525^{*}$ \\
\hline & $\mathrm{NH}_{4}^{+}$ & $0.797^{* *}$ \\
\hline & $\mathrm{pH}$ & $-0.436^{*}$ \\
\hline \multirow{3}{*}{$\mathrm{C}_{\text {humic }}$} & Color & $0.537^{*}$ \\
\hline & $\mathrm{NH}_{4}^{+}$ & $0.837^{* *}$ \\
\hline & $\mathrm{pH}$ & $-0.487^{*}$ \\
\hline \multicolumn{3}{|c|}{ December } \\
\hline \multirow{3}{*}{$\mathrm{C}_{\text {total }}$} & Color & $0.791^{* *}$ \\
\hline & $\mathrm{NH}_{4}^{+}$ & $0.424^{*}$ \\
\hline & $\mathrm{pH}$ & $-0.459^{*}$ \\
\hline \multirow{3}{*}{$\mathrm{C}_{\text {humic }}$} & Color & $0.775^{\star *}$ \\
\hline & $\mathrm{NH}_{4}^{+}$ & $0.426^{*}$ \\
\hline & $\mathrm{pH}$ & $-0.488^{*}$ \\
\hline
\end{tabular}

* Significantly at $\mathrm{p}=0.001$.

** Significantly at $\mathrm{p}=0.05$.

off (Table 3). The correlation between these parameters in May samples was insignificant. This situation can be attributed to agricultural activity, mostly cultivation of plants.

The analysis of dissolved humic substances in water samples was made by the Górniak method [1995]. Results showed that the contents of $C_{\text {humic }}$ varied between objects and terms of determina- tion (Table 2). Most of the dissolved humic substances were of terrestrial origin and showed no indication of significant removal during transit to the groundwater [Aiken and Cotsaris, 1995; Collins et al., 1986]. During the transport toward the groundwater these humic substances diluted in waters containing lower concentrations of carbon comparison with soil humic substances.

The analyzed groundwater contained mainly fulvic acids. Dissolved fulvic acids, an important part of dissolved organic matter, appeared more oxidized and were depleted in nitrogen and aliphatic structures compared to soil fulvic acids [Aiken and Cotsaris, 1995; Tremblay and Gagne, 2009; Watt et al., 1996]. Extraction of the analyzed humic substances demonstrated low content of aromatic particles (acidification did not separate humus substances into fractions). Our earlier studies confirmed this situation and showed that $\mathrm{A}_{260} / \mathrm{A}_{330}$ (which characterize the quality of dissolved organic substances), according to Górniak [1995] and Gołębiowska [2004]) are within the range of 2.14-3.60. This index also showed that groundwater lacks polymer particles and it does not contain great amounts of compounds with carboxylic groups. This is consistent with other literature values of character of 


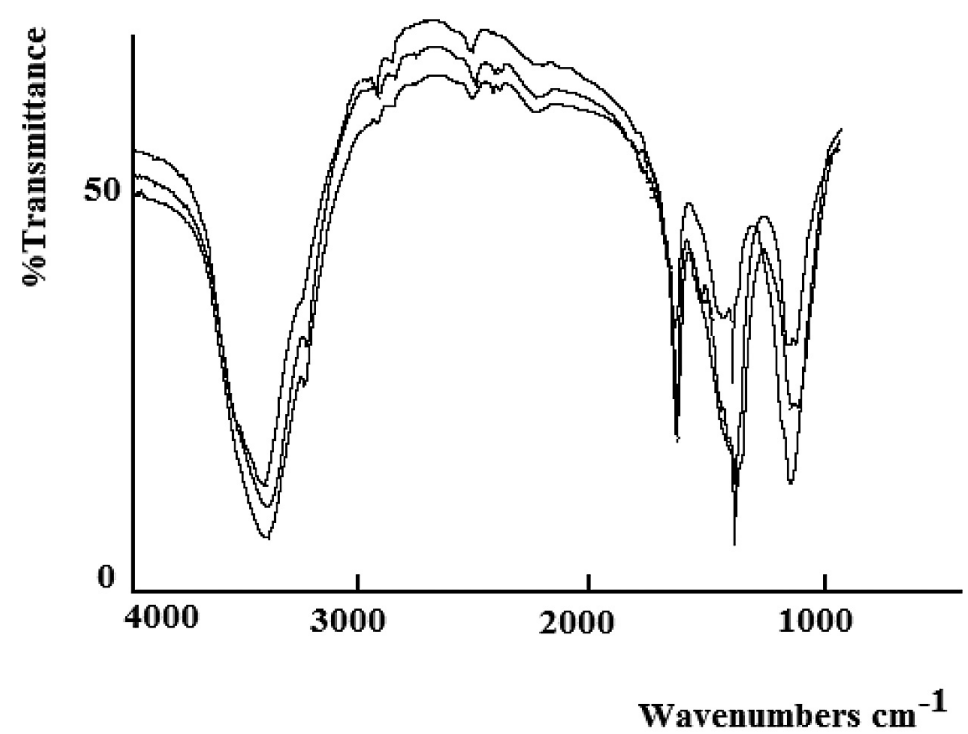

Figure 4. FT-IR spectra of humic substances from selected water samples

aquatic humic substances [Huo et al., 2009; Malcolm, 1990; Newcombe et al., 1997; Stevenson, 1994] and confirms low concentration of carbon in carboxylic groups in groundwater. The general trends shown by fractions from the water samples are similar, however, the percentage of carbon in aquatic humic substances differs (Table 2).

This conclusion can be also confirmed by FT-IR-analysis (Figure 4). In some organic substances of water samples we observed the same absorption zones as in soil's humus substances (similarity to soil's fulvic acids [Collins et al., 1986; Malcolm, 1990; Newcombe et al., 1997; Pisarek and Głowacki, 2005; Stevenson, 1994; Watt et al., 1996]). A broad band at 3300-3600 $\mathrm{cm}^{-1}$ corresponding to stretching vibration of $\mathrm{OH}$ groups was present in each spectrum. Low vibration was observed at $2920 \mathrm{~cm}^{-1}\left(\mathrm{CH}_{2}\right.$ and $\mathrm{CH}_{3}$ aliphatic). The $\mathrm{C}=\mathrm{O}$ vibrations in carboxyl and carbonyl groups and $\mathrm{C}=\mathrm{C}$ aromatic bands in the $1600-1800 \mathrm{~cm}^{-1}$ region were so weak. The wide absorption region were found: $1440-1460 \mathrm{~cm}^{-1}$ (C-H aliphatic) and clear absorption at 1200-1275 $\mathrm{cm}^{-1}$ (attributable to a carboxyl groups and $\mathrm{OH}$ of phenols). There was a very wide and intense band in the region between 1000 and $1150 \mathrm{~cm}^{-1}(\mathrm{OH}$ of tertiary alcohols and polysaccharides). These findings are consistent with trends observed in others papers [Aiken and Cotsaris, 1995; Artinger et al., 2000; Collins et al., 1986; Lydersen et al., 1996; Smith and Katharina, 2007; Stevenson, 1994; Tremblay and Gagne, 2009].

Summary, organic carbon adsorption in soils has been suggested as an important mechanism controlling organic carbon transport and leaching, and consequently the buffering of dissolved organic carbon concentration (involving mobile forms of humic substances) in water ecosystems [Mattson and Kortelainen, 1998].

\section{CONCLUSIONS}

1. The groundwater in the St. Anna Mountain region shows high diversity in quality. The main threat for the quality of water in this region is the human household activity.

2. The main pollutants of groundwater in St. Anna Mountain region are: dissolved phosphorus, nitrate and ammonium.

3. The analyzed ground water contained mainly fulvic acids. Extraction of humus substances demonstrated low content of aromatic particles.

4. FTIR analysis showed similarity of groundwater humus substances to soil fulvic acids. It can indicate the possibility of translocation of mobility soil humic substances to the groundwater.

\section{REFERENCES}

1. Aiken G., Cotsaris E., 1995. Soil and hydrology: their effect on NOM. J.AWWA. 87(1), 36-45.

2. Aiken G.R., 1985. Isolation and concentration techniques for aquatic humic substances. In: Humic substances in soil, sediment and water: Geo- 
chemistry, isolation and characterization. Aiken G.R., McKnight D.M., Wershaw R.L., MacCarthy P. (Eds.). John Wiley\&Sons, New York, 363-385.

3. Allahbakhh A., Yaghmaeian K., Abbasi E., Roudbari A., 2014. An evaluation of water quality from Mojen River, by NSFWQI index. Journal of Ecological Engineering, 15(4), 1-6.

4. Artinger R., Buckau G., Geyer S., Fritz P., Wolf M., Kim J.I., 2000. Characterization of groundwater humic substances: influence of sedimentary organic carbon. Applied Geochemistry, 15 (1), 97-116.

5. Arvola L., Tulonen T., 1998. Effects of allochthonous dissolved organic matter and inorganic nutrients on the growth of bacteria and alge from highly humic lake. Environmental International, 24(5/6), 509-520.

6. Collins M.R., Amy G.L., Steelink C., 1986, Molecular weight distribution, carboxylic acidity and humic substances content of aquatic organic matter: implications for removal during water treatment. Environ. Sci. Technol. 20, 1028-1032.

7. Ephraim J.H., Petterson C., Allard B., 1996. Correlations between acidity and molecular size distributions of an aquatic fulvic acids. Environmental International, 22(5), 475-483.

8. Gołębiowska D., 2004. Absorption spectrophoto-metry in UV-VIS range: parameters and way of analysis of humic compounds absorption. In: Gołębiowska D. (Eds.) Methods of investigation of humic substances of water and land ecosystems. .AR, Szczecin, 15-26.

9. Górniak A., 1995. Spectrometric method of analysis of concentration and quality of organic carbon in water. Water Management, 2, 31-33.

10. Górniak A., 1996. Humus substances and their role in the freshwater ecosystems. Diss. Univ. Vars. 448, pp. 135.

11. Huo S., Xi B., Yu H., Liu H., 2009. Dissolved organic matter in leachate from different treatment processes. Water and Environ. Journal, 23, 15-22.

12. Kononova M.M., 1966. Soil Organic Matter. Pergamon Press, Oxford, pp. 383.

13. Lydersen E., Fjeld E.,Gjessing E.T., 1996. The humic lake acidification experiment (HUMEX): main physico-chemical results after five years of artificial acidification. Environment International, 22(5), 591-604.

14. Malcolm R.L, 1990. The uniqueness of humic substances in each of soil, stream, and marine environments. Anal. Chim. Acta. 232, 19-30.
15. Mattson T., Kortelainen P., 1998. Dissolved organic carbon fractions in Finnish and Maine (USA) lakes. Environmental International, 24(5/6), 521-525.

16. Newcombe G., Hepplewhite C., Pelecani C., Drikas M., Snoeyink V., 1997. Comparison of characteristics of fractionated NOM from two reservoirs. Drozd J.,Gonet S.S., Senesi N., Weber J. (eds.):" The Role of Humic Substances", IHSS, 629-634.

17. Pisarek I., 2003. Characterization of humic substances formed in soil fertilized with sewage sludge and cattle manure. Humic Substances and Ecosystems, 5, 93-99.

18. Pisarek I., Głowacki M., 2005. Some properties of aquatic humic substances from underground water of Opole region. Polish Journal of Environmental Studies, 14, 29-32.

19. Pisarek I., Głowacki M., 2009. Soil and water humic substances in groundwater reservoir area No 333 in Opole district (Poland). Rocz. Glebozn. 60 (2), 47-52.

20. Porowska D., 2014. Assessment of groundwater contamination around reclaimed municipal landfill - Otwock area, Poland. Journal of Ecological Engineering, 15(4), 69-81.

21. Regulation of the Polish Ministry of the Environment, 2008. 143, poz. 896.

22. Smidt E., Katharina M., 2007. The applicability of Fourier transform infrared (FT-IR) spectroscopy in waste management. Waste Manage. 27, 268-276.

23. Steinberg Ch.E.W., Pflugmacher P.S., Meinelt T., Klocking R., Wiegand C., 2003. Pure humic substances have the potential to act as xenobiotic chemicals - a review. Frasen. Environ. Bull. 12, 391-401.

24. Stevenson F.J., 1994. Humus chemistry: Genesis, Composition, Reactions. John Wiley \& Sons. New York. pp. 348.

25. Tremblay L., Gagne J.P., 2009. Organic matter distribution and reactivity in the waters of large estuarine system. Marine Chemistry.116, 1-12.

26. Watt B.E., Malcolm R.L., Hays M.H.B., Clarck N.W.E., Chipman J.K., 1996. Chemistry and potential mutagenicity of humic substances in waters from different watersheds in Britain and Irleand. Water Res. 30, 1502-1516.

27. Zieliński P., 2004. Distribution of dissolved organic carbon in north-eastern Poland rivers. In: Golebiowska D. (Ed.) Methods of investigation of humic substances of water and land ecosystems. AR, Szczecin, 93-98. 